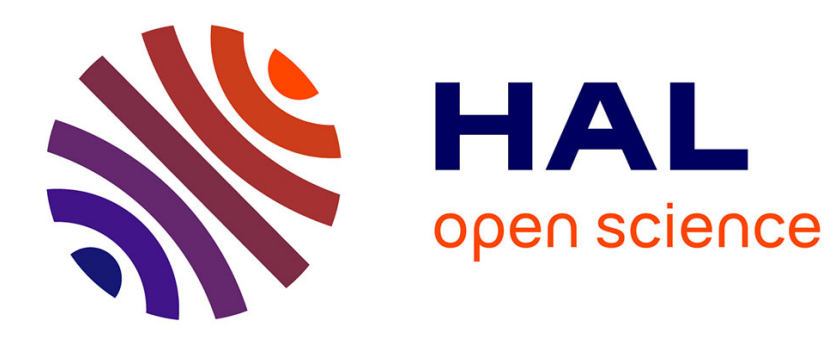

\title{
Methods of activating and recrystallizing thin films of II-VI compounds
}

\author{
A. Vecht
}

\section{To cite this version:}

A. Vecht. Methods of activating and recrystallizing thin films of II-VI compounds. Revue de Physique Appliquée, 1966, 1 (3), pp.194-194. 10.1051/rphysap:0196600103019400 . jpa-00242714

\section{HAL Id: jpa-00242714 https://hal.science/jpa-00242714}

Submitted on 1 Jan 1966

HAL is a multi-disciplinary open access archive for the deposit and dissemination of scientific research documents, whether they are published or not. The documents may come from teaching and research institutions in France or abroad, or from public or private research centers.
L'archive ouverte pluridisciplinaire HAL, est destinée au dépôt et à la diffusion de documents scientifiques de niveau recherche, publiés ou non, émanant des établissements d'enseignement et de recherche français ou étrangers, des laboratoires publics ou privés. 


\section{METHODS OF ACTIVATING AND RECRYSTALLIZING THIN FILMS OF II-VI COMPOUNDS}

\section{A. VECHT}

Associated Electrical Industries Ltd., Central Research Laboratory, Rugby, Warwickshire, England.

Résumé. - On passe en revue les méthodes d'activation et de recristallisation des couches minces de composés II-V'I. On discute d'abord l'importance de la pureté des matériaux de départ, et de la stoechiométrie des couches déposées, puis les effets de l'activation et de la recristallisation, plus particulièrement en vue de la préparation de couches minces qui présentent des propriétés physiques utiles.

On insiste sur les techniques organométalliques, d'incorporation, de dépôt chimique, ainsi que sur les méthodes d'évaporation multiple et de chauffage après évaporation. Les mérites relatifs de ces méthodes sont indiqués.

Abstract. - A review ( 1 ) of methods of activating and recrystallizing thin films of II-VI compounds is made. After discussing the importance of the purity of the starting material and the stoichiometry of the deposited films, the effects of activation and recrystallization are discussed, more especially in relation to the preparation of films showing useful physical properties.

The organometallic, embedding and chemical deposition techniques are outlined as well as multiple evaporation and post-evaporation heating methods. The relative merits of these methods are assessed.

(1) This review is based in part on a chapter in Physics of Thin Films, vol. III, edit. G. Hass and R. E. Thun, Academic Press, New York. 